\title{
A RENDA DA TERRA E A RENDA DA VIDA NOS MEANDROS DO LABIRINTO DO CAPITAL
}

Thiago da Silva Melo

Mestrando em Geografia na Universidade Estadual de Londrina thiago_dasilvamelo@yahoo.com.br

Resenha recebida em 07/02/2016 e aceita para publicação em 18/11/2016

DOI: $10.12957 /$ tamoios.2016.21459

BARTRA, Armando. El capital en su labirinto: de la renta de la tierra a la renta de la vida. Ciudad de México: UNAM, 2006.

Esta resenha, apresenta considerações sobre o livro El capital en su labirinto: de la renta de la tierra a la renta de la vida, no qual, Armando Bartra reúne seus principais textos de caráter teórico, ao longo de 45 anos de estudos, trazendo diversos elementos que auxiliam na compreensão da função do campesinato como classe social e produtora.

Armando Bartra é formado em Filosofia e Economia na Universidade Nacional Autônoma do México (UNAM), mestre em Antropologia Social, recebeu o título Doutor Honoris Causa da Universidade Nacional de Córdoba, Argentina. Foi diretor do Instituto de Estudos para o Desenvolvimento Rural Maya, foi professor na Faculdade de Economia, História, Sociologia, Ciência Política e Antropologia da Universidade Nacional Autônoma do México.

Em sua obra, traz reflexões sobre a questão agrária de maneira transdisciplinar, englobando Sociologia, História, Geografia, Antropologia e Ciência Política. Seu enfoque principal é sobre o campesinato em suas múltiplas dimensões.

O livro está dividido em três partes: na primeira, o autor discorre sobre a luta dos camponeses pela posse da terra como elemento indispensável para sua reprodução, na segunda, realiza uma análise pontual sobre as classes sociais e as relações de produção abordadas pelo viés marxista através da teoria da renda da terra, na terceira parte, elabora um panorama da relação dialética entre a questão agrária e o capitalismo.

No contexto atual, se observa um cenário complexo e diverso no espaço agrário em uma realidade repleta de desigualdades que se manifestam em uma crise na soberania alimentar, no uso abusivo das chamadas tecnologias que destroem os ecossistemas, reduzem as terras produtivas, causam a migração e precarizam o trabalho no campo.

O início deste processo remonta ao século XIX dando início também à luta do movimento camponês por melhores condições de trabalho, produção e comercialização 
$\overline{\text { de seus produtos, neste sentido, Bartra evidencia os encontros e desencontros na formação }}$ do movimento.

É observada uma heterogeneidade e dispersão no movimento camponês de luta pela terra pela diversidade dos sujeitos que a compõe, no entanto, estes diversos atores tem um forte ponto convergente que diz respeito à resistência frente o avanço do capital e sua exploração.

O autor apresenta críticas ao papel atribuído ao agronegócio na modernidade, analisando a renda e o modo de produção camponês, sua exploração e seu papel no sistema global a partir de suas observações no México.

Ao analisar o movimento camponês, Bartra o considera dividido em três frentes de luta: um primeiro grupo, formado por pequenos e médios produtores, por melhores preços, condições de produção e comercialização; um segundo grupo, composto por trabalhadores assalariados do campo, por maiores salários e diminuição da jornada de trabalho; um terceiro grupo é composto por todos os oprimidos, unidos contra a repressão e a imposição.

Como estratégia de luta, existem duas vertentes no cerne do movimento: a primeira seria a militarização como único caminho e a segunda de que a proletarização dos camponeses seria a única via para mudanças.

Quanto às possibilidades de uma reinvindicação política através da luta, Bartra levanta duas questões que ocupam grande parte do livro. Verifica-se as especificidades dos produtos agrícolas e a força de trabalho. Os produtos agrícolas estão ligados, com renda da terra, que pode ser entendida como mediadora econômica entre o setor industrial e a agricultura. A força de trabalho é compreendida enquanto referência à condição da classe camponesa como explorada conforme os interesses do capital.

O autor dá continuidade à discussão abordando a temática renda da terra a partir de seu principal aspecto que é o desenvolvimento desigual da indústria e da agricultura, de tal forma que os camponeses são indispensáveis nesse processo de acumulação primitiva do capital através de sua exploração em uma relação perversa.

A teoria da renda permite compreender as diferentes relações entre indústria e agricultura, entre proprietários de terra e produtor agrícola. De maneira que mesmo sendo pré-capitalista, persiste na medida em que o sistema se ajusta à realidade.

A partir da segunda metade do século XX, com o desenvolvimento de tecnologias monopolizadas que permitiram, por exemplo, o advento da modernização da agricultura por meio da Revolução Verde, houve a disseminação do mito de que a técnica do uso de 
$\overline{\text { fertilizantes químicos, aplicação de agrotóxicos e modificação genética de sementes }}$ resolveriam o problema da fome, dando início ao que o autor denomina de renda da vida, uma nova etapa da renda da terra possibilitada pelo avanço da biotecnologia.

Os artificiosos procedimentos de produção e a impetuosidade dos mesmos para com os bens naturais e o trabalho humano atingem níveis de exploração jamais vistos. De acordo com Bartra, tal modelo forjado através das mudanças capitalistas na tecnologia, propiciou a conjuntura para a privatização e comando de todas as áreas da vida, com consequências que, a seu ver, colocam em risco a continuação da humanidade.

Dentro dessa discussão, a terra é um elemento central e se comporta de maneira diferente dos meios de produção do setor industrial, por ser um bem natural finito e que não pode ser produzido pelo trabalho humano, o que altera a lógica de produção capitalista no campo.

Quanto à questão de significado histórico e as possibilidades de uma reivindicação política do movimento camponês através da luta, Bartra evidencia especificidades que figuram em grande parte da discussão do livro. A singularidade dos produtos agrícolas como as commodities, e as características resultantes da força de trabalho. Os produtos agrícolas se relacionam, na análise do autor, com renda da terra, que pode ser entendida como mediadora das relações econômicas entre a indústria e a agricultura.

Armando Bartra faz uma excelente análise com instrumentos teóricos essenciais, que necessitam ser melhor estudados pelos que desejam compreender a questão agrária e em especial a renda da terra. Para a compreensão de qualquer processo econômico, político e social, o marxismo é uma ferramenta essencial e Bartra com grande habilidade utiliza de forma precisa esta ferramenta em seu trabalho. 